\title{
Communication is key to aid development efforts
}

\author{
Government could hone its use of science but scientists need to understand the issues.
}

Sir - Recent calls by the United Nations (Nature 430, 5; 2004) for stronger science input to support aid policy, in particular for feeding the hungry, are welcome. In the United Kingdom, organizations such as the Department for International Development (DFID) need to improve their use of the science base. But there is also scope for the scientific community to improve its understanding of development issues surrounding agricultural policy, if scientists are to be productively engaged in fighting world hunger and poverty.

In the United Kingdom, the call for better use of science in development has been led by the Royal Society and the science research councils. In a recent News story (Nature 429, 492; 2004), John Lawton, of the Natural Environment Research Council, described DFID as "complacent, rather arrogant and illinformed" about science.

However, similar shortcomings with respect to understanding of development issues are evident in the public pronouncements of some of the country's leading scientists.

At the same parliamentary inquiry at which Lawton addressed DFID's shortcomings, John Pickett, of the Biotechnology and Biological Sciences Research Council, described how, on a visit to Malawi, his team was "whisked off" to view "some kind of DFID programme in which very, very small bags of seed and very, very small bags of fertilizer were being given out.... This seemed to be a totally unsustainable and non-scientific based [sic] piece of development work which you would not really expect of an organisation like DFID".

The programme Pickett refers to is known as the Malawi Starter Pack Programme, which, in the 1998 and 1999 planting seasons, aimed to supply Malawi's 2.8 million smallholder farming households with sufficient inorganic fertilizer and hybrid maize seed to plant 0.1 hectare (the average land-holding in southern Malawi is $0.3 \mathrm{ha}$ ). These "very, very small" inputs were intended to provide a short-term safety net, to enable Malawi's farmers to survive the consequences of the International Monetary Fund's Structural Adjustment Programme. This had withdrawn subsidies from agricultural inputs (including fertilizer), ordered a dramatic currency devaluation and caused (through withdrawal of state services) the collapse of the agricultural credit system. As a result, most farmers were unable to afford the inputs needed to grow enough food for household consumption (see http:// web.africa.ufl.edu/asq/v6/ v6ila8.htm).

Far from being unscientific, the Starter Pack programme was based on a thorough knowledge of the constraints faced by farmers and the production dynamics of Malawian agriculture. The programme was designed by Charles Mann, an economist at Harvard's John F. Kennedy School of Government and former food security adviser to Malawi's government. DFID provided much of the funding for the programme, but its implementation was a multi-donor effort.

With the secretary of state for international development, Hilary Benn, having recently confirmed that DFID will appoint a chief scientist, there are good opportunities for science to serve development needs, provided there is effective communication on both sides.

Edward H. Allison

School of Development Studies,

University of East Anglia,

Norwich NR4 7TJ, UK

\section{Proud past but no future for pioneering institute}

Sir - As reported in your News story "Institute doomed by loss of interest in basics" (Nature 430, 282; 2004), Japan's Biomolecular Engineering Research Institute (BERI) will disband sometime next year. Unfortunately, for various reasons, including the fact that the board of directors had not yet met to finalize its decision, I was unable to comment at the time.

During the past 18 years, BERI has achieved much in the field of protein structure and functional analysis.

Many scientists starting at BERI have gone on to excellent positions in industry or academia. BERI has been highly reputed both at home and abroad and it has amply succeeded in attaining its original goals.

But in changing times that increasingly call for research geared towards practical developments, it has become difficult to reconcile the interests of basic research with varied corporate needs.

BERI's project grants from the government have fallen by half during recent years, increasing the burden on industry. And a government evaluation on 25 March this year, while praising the projects' technological merits, criticized their wider applicability.

As chairman of the board of directors and a founding member of BERI, I find it regrettable but unavoidable that the nine companies supporting BERI have decided, in consultation with the Ministry of Economy, Trade and Industry, to disband it.

Many important issues remain, such as how to bring ongoing projects to fruition and how to support the relocation of experienced researchers and staff. I predict that there will be many employers eager to take them in.

\section{Tadashi Hirata}

Biomolecular Engineering Research Institute,

6-2-3 Furuedai, Suita-shi, Osaka 565-0874, Japan

\section{Plant biologists need to get back to their roots}

Sir - Sean Nee is right in drawing attention to the invisible world of microbial life in his Commentary "More than meets the eye" (Nature 429, 804-805;
2004). That netherworld of life is not the only one to suffer neglect on the part of biologists, however. The microscopic life in the soil depends in large measure on plants exporting to their roots the sugars produced by photosynthesis in their leaves. But biology - even plant biology — is obsessed with the visible plant.

Mother Nature conspires with biologists to keep plant roots in the dark. Yet all visible life on the surface depends, for most of the chemical elements it requires (the mineral nutrients), on plant roots which are 'out of sight, out of mind'.

Anyone wanting to test the neglect of this matter need only try looking up 'plant nutrition' in university catalogues. That science, so prominent half a century ago, has all but lost an identity of its own. Pretending that this subject belongs in soil science is like considering photosynthesis as part of atmospheric science. The roots of life on Earth deserve better.

Emanuel Epstein

College of Agricultural and Environmental Sciences, University of California, Davis,

One Shields Avenue, Davis,

California 95616, USA 